\title{
IMAGENS SUSSURRANTES: CINEMA DE FLUXO E TEMPO MÍTICO EM HISTÓRIAS QUE SÓ EXISTEM QUANDO LEMBRADAS
}

Fabrício Basílio Pacheco da Silva (UFF)

Maurício de Bragança (UFF)

Recebido em 04 fev 2018. Fabrício Basílio Pacheco da Silva é mestrando em Aprovado em 24 abr 2018. Comunicação pela UFF, tem interesses nas áreas de cinema fantástico, cinema e literatura e cinema contemporâneo.

Maurício de Bragança é doutor em Letras pela UFF, professor do Departamento de Cinema e do Programa de pós-graduação em Cinema e Audiovisual da UFF, bolsista de produtividade em pesquisa CNPq - Nivel2, autor de A traição de Manuel Puig: melodrama, cinema e política em uma literatura à margem (EdUFF, 2010) e organizador, junto com Marina Tedesco de Corpos em projeção: gênero e sexualidade no cinema latino-americano (7Letras, 2013) e trabalha com cinema e literatura, cinema latino-americano, estudos de gênero e cultura midiática na América Latina. CV_Lattes: http://lattes.cnpq.br/8492998821902029. Email: mauriciode@yahoo.com

Resumo: $\mathrm{O}$ artigo tem o objetivo de tensionar cinema e literatura a partir do insólito produzido em Histórias que só existem quando lembradas (Bra/Arg/Fra, 2011), de Julia Murat. Associamos primeiramente o filme ao cinema de fluxo, estética que aposta na 
sensorialidade, em filmes com narrativas rarefeitas, nas quais a noção de espaço-tempo é ressignificada a partir da dilatação do plano. A partir disso, buscamos pistas para análise na literatura, convocando Pedro Páramo, de Juan Rulfo, como lugar teórico capaz de fornecer paralelos entre as obras do escritor mexicano e de Julia Murat e também nas discussões sobre transculturação narrativa, apresentadas por Ángel Rama. O que nos move aqui é perceber esse gesto evanescente presente no filme, como uma espécie de "imagens sussurrantes", de existência efêmera, vinculadas ao universo do insólito também construído em Pedro Páramo. Desta forma, o filme se utiliza da estética do fluxo se aproximando da ideia de transculturação alcançada pelos procedimentos literários que renovaram a narrativa dos escritores na América Latina.

Palavras-chave: Insólito; Cinema de fluxo; Transculturação narrativa; Tempo mítico; Cinema brasileiro contemporâneo.

Abstract: The article has the object of analyzing cinema and literature from the unusual produced in the film Found Memories (Bra / Arg / Fra, 2011), by Julia Murat. We first associate the film with the flow cinema, aesthetic that bets on sensoriality, in films with rarefied narratives, in which the notion of spacetime is re-signified from the long shots. From this, we search tracks for analysis in the Literature, ponting to Pedro Paramo, by Juan Rulfo as a theoretical place capable of providing parallels between the work of the Mexican writer and Julia Murat, and in the discussions on narrative transculturation, presented by Ángel Rama. We intend to perceive this evanescent gesture present in the film, as a kind of "whispering images", of ephemeral existence, linked to the unusual universe also built in Pedro Páramo. In this way, the film uses the aesthetics of the flow to approach to the transculturation developed by the 
literary procedures that renewed the narrative of writers in Latin America.

Keywords: Unusual; Flow cinema; Narrative transculturation; Mythical time; Contemporary Brazilian cinema.

\section{INTRODUÇÃO}

- ¿No me oyes? - pregunté en voz baja. Y su voz me respondió: - ¿Dónde estás? - Estoy aquí, en tu pueblo. Junto a tu gente. ¿No me ves? - No hijo, no te veo. Su voz parecía abarcarlo todo. Se perdía más allá de la tierra. - No te veo. (Pedro Páramo, Juan Rulfo)

O filme de estreia da diretora Julia Murat, Histórias que só existem quando lembradas ( $\mathrm{Bra} / \mathrm{Arg} / \mathrm{Fra}, 2011)$, carrega, já no título, o paradoxo em torno da memória e do esquecimento, tornando $\mathrm{o}$ ato de recordar algo evanescente, prestes a escapar e se dissolver, mas que se recupera pelo sutil gesto da lembrança, ou da presença, como algo passageiro e transitório. $\mathrm{O}$ filme foi recebido com entusiasmo pela crítica, que logo percebeu gestos poéticos e a construção de uma atmosfera em Jotuomba que remetia ao universo do realismo fantástico latino-americano, especificamente a Comala de Pedro Páramo, de Juan Rulfo.

O filme apresenta a rotina de um pequeno vilarejo habitado unicamente por idosos, mas com o cemitério fechado. O espaço nos é revelado através do cotidiano de Madalena - o fazer do pão, 
o café da manhã na bodega, a missa, o almoço e as cartas escritas à luz de lampião. Esta rotina se repete diariamente e é perturbada pelo surgir da jovem fotógrafa Rita, que começa a questionar a existência desse espaço perdido no tempo e de memórias perdidas na escuridão.

A Comala, de Rulfo, também se apresentava como um lugar onde as memórias se dissipavam nas frestas, nos fragmentos de vozes sussurradas ouvidas ao longe, nos passos perdidos pelos corredores mal iluminados. Esse mesmo universo, repleto de figuras do insólito, viria inspirar o longa metragem de estreia de outro diretor, o documentarista Juan Carlos Rulfo, filho do escritor mexicano, que daria ao filme sobre a memória do seu pai o título de Del olvido al no me acuerdo (México, 2011), confirmando esse paradoxo que destacamos no início, entre lembrança e esquecimento.

Murat assumiu a inspiração, ressaltando que "queria destacar esse realismo mágico, especialmente Pedro Páramo, que era a principal referência, mas também Gabriel García Márquez e um pouco menos (Jorge Luis) Borges"1. Ao mesmo tempo em que se inspira em um arcabouço literário, o filme também se associa a uma forma de construir as imagens e sons que ganhou força nas últimas duas décadas entre cineastas que, como Murat, apostam na sensorialidade, repensando a mise-en-scène, em filmes com narrativas rarefeitas, nas quais a noção de espaço-tempo é ressignificada a partir da dilatação do plano ${ }^{2}$. Nestes filmes, o plano

1 Informação extraída do site: https://www.terra.com.br/diversao/cinema/julia-muratapresenta-filme-no-festival-de-veneza,ca3c62809746a310VgnCLD200000bbcceb0aRC RD.html Acesso em 12.Jan.2018.

2 Nesse artigo usamos o termo "plano" a partir de suas duas definições mais correntes. Primeiro como menor unidade de significado do cinema, delimitado na estrutura fílmica pela existência de um corte de uma imagem para outra. E segundo como sinónimo de 
não opera necessariamente como um articulador de significados narrativos, o que acabou por ajudar a nomear este repertório como "cinema de fluxo" (BOUQUET, 2002; OLIVEIRA JUNIOR, 2013). É importante atentar para o fato de que este gesto estético não se articula como um "movimento cinematográfico", mas como um "comportamento do olhar" (OLIVEIRA, 2013, p.08), que vem se contrapor à herança narrativa do cinema em filmes que tomam a forma de:

um fluxo esticado, contínuo, um escorrer de imagens nas quais se abismam todos os instrumentos clássicos mantidos pela própria definição da mise-en-scène: o quadro como composição pictural, o raccord como agente de significação, a montagem como sistema retórico, a elipse como condição da narrativa. (LALANNE, 2002, p.26) ${ }^{3}$

Ao apresentar códigos do cinema de fluxo, o filme de Murat passa a trabalhar com uma narrativa rarefeita, de acontecimentos mínimos, que substituem a dramatização da cena pela contemplação de pequenos gestos do cotidiano. Explorando a sensorialidade da imagem e do som a partir de uma temporalidade capaz de construir uma atmosfera opaca, o filme se distancia de uma representação clássica da narrativa cinematográfica e nos obriga a buscar outras ferramentas de análise.

\footnotetext{
"quadro ou enquadramento", servindo principalmente para apontar diferentes escalas na construção da imagem (geral, conjunto, fechado) e a existência ou não de movimento de câmera (plano fixo, plano em movimento).

3 As traduções, quando não identificadas a autoria, são de responsabilidade dos autores do artigo. "Un Flux tendu, continu, un coulé d'images dans lequel s'abîment tous les outils classiques tenus pour la définition même de la mise-en-scène: le cadre comme composition picturale, le raccord comme agent de signification, le montage comme système rhétorique, l'ellipse comme condition du récit."
} 
Neste sentido, uma das estratégias deste artigo é convocar a obra de Juan Rulfo não como um texto original diante do filme de Murat, uma vez que a obra da cineasta não é uma adaptação cinematográfica de Pedro Páramo, mas pensar o romance como um lugar teórico, capaz de oferecer pistas importantes para a leitura de Histórias que só existem quando lembradas. Assim, daremos à obra de Rulfo o mesmo estatuto que a de escritores teóricos, recorrendo às letras do romance como forma de problematizar as imagens do filme.

Nesse percurso, outro argumento se apresenta como uma pista importante: as discussões sobre transculturação narrativa, trazidas pelo crítico literário Ángel Rama. Através do seu clássico estudo sobre a renovação da narrativa hispano-americana na segunda metade do século $X X$, evidenciaremos alguns pontos que nos ajudam a pensar a presença de Rulfo em Murat, sem, no entanto, construir hierarquias entre os dois textos. $\mathrm{O}$ que nos move aqui é perceber esse gesto evanescente presente no filme, como uma espécie de "imagens sussurrantes", de existência efêmera, vinculadas ao universo do insólito também construído em Pedro Páramo, e que irrompem na tela, destinadas ao desaparecimento. Desta forma, o filme se utiliza da estética do fluxo como meio de estabelecer a transculturação alcançada pelos procedimentos literários que renovaram a narrativa dos escritores na América Latina. Cabe esclarecer que não nos motiva, aqui, pensar a obra de Lucia Murat como um exemplo de transculturação narrativa no cinema, mas tomar das reflexões de Rama, pistas para uma leitura do filme, aproveitando a chave apresentada pela crítica cinematográfica e pela própria diretora. 
Diante disso, o que propomos a seguir é delimitar os traços preponderantes do cinema de fluxo e as pistas que Pedro Páramo e Ángel Rama nos fornecem, buscando imbricar esses saberes à análise do filme.

\section{CINEMA DE FLUXO}

Como pontua Luiz Carlos Oliveira Junior (2013), o cinema de fluxo "é uma estética derivada de um olhar não mais diante do mundo, mas sim um olhar imerso no mundo, ou num 'intermundo'” (p.152). Nesse meio "o plano muda de estatuto, já não é mais 'a parte de um todo', ou 'a menor unidade de significação no cinema', mas antes um recorte 'aleatório' do fluxo irrefreável das aparências que constituem o real (ou sua ilusão)" (OLIVEIRA JUNIOR, 2013, p.151).

Assim, a narrativa clássica cinematográfica baseada no plano (menor unidade de significação no cinema) - da qual os cineastas partem para a construção de uma mise-en-scène com o intuito de organizar o caos, moldando o abstrato e imprimindo neste um sentido, uma racionalidade - é abandonada no cinema de fluxo em prol de filmes que não possuem a intenção de organizar uma miseen-scène, e sim de apresentá-la em suas formas irracionais a partir do "princípio de um desencadeamento permanente e infinito" (BOUQUET, 2002, p.47) 4 . Essa estética "só se torna como tal por um processo de abstração de qualquer princípio de identidade, permanência, lógica. Ele já não diz que ele é algo (um enredo, uma definição), mas que ele é outra coisa: imagem ou homem ou animal ou ser ou tudo"5 (BOUQUET, 2002, p.47).

4 "principe de défilement permanent et infini"

5 "Cinéma du flux ne devient tel que par un processus d'arrachement à tout principe 
Para que esse efeito seja criado, a narrativa é triturada e pulverizada em diversas situações cotidianas e os personagens construídos acima de tudo por seus corpos em movimento no espaço-tempo do plano. Assim, as ações e os diálogos são muitas vezes pistas falsas, que não motivam o encadeamento de uma trama, pois, a estética do fluxo trabalha com a desdramatização da cena: "sem a esquemática lógica narrativa aristotélica, sem grandes confrontações psicológicas ou de ação" (ORSINI, 2017, p.70 -71).

A ausência de uma narrativa clara reverbera em elipses e silêncios que, muitas vezes, embaralham a possibilidade de acontecimentos e ajudam a construir "um mundo pontilhado de buracos e desaparecimentos, de forças contraditórias e complementares" (JOYARD, 2003, p.27) ${ }^{6}$. Chega-se a um cinema de atmosferas, no qual a câmera está interessada em afetar o espectador com "uma profusão sensorial que parece em sintonia com um estado vaporoso do mundo, com uma nova realidade em que as relações de espaço-tempo se acham em processo de interpenetração e confusão" (OLIVEIRA JUNIOR, 2013, p.09). Por este motivo, como em Histórias que só existem quando lembradas, muitos desses cineastas tem predileção pelo plano geral de longa duração, no qual o tempo se torna uma "suspensão transitória" (CUNHA, 2014, p.48) capaz de "aprisionar" no mesmo quadro corpo e espaço físico, movimento e fixidez, gesto e permanência, que são recolhidos a partir dos fragmentos que constituem o filme. définition) mais qu'il est autre chose aussi: image ou homme ou animal ou être ou tout." 6 "un monde parsemé de trous e de disparitions, de forces contradictoires et complemetaire" 
O meio essencialmente psicológico do cinema narrativo é trocado por uma zona sub ou quiçá supralógica. O filme até oferece possiblidades de significação e permite interpretações nuançadas de seu conteúdo, mas sua eficácia maior consiste em agitar a consciência do espectador com infinitas hipóteses não conclusivas. (OLIVEIRA JUNIOR, 2013, p.167)

O cinema de fluxo barra o olhar que tudo quer organizar e a mente que tudo quer entender e racionalizar. Para Emiliano Fischer Cunha essa barreira está relacionada a "resistência inconsciente" de um espectador acostumado com "figuras extraordinárias, ativas e reativas", e que se depara nesse filme com situações ordinárias (2014, p.49). Porém, não se trata de um cinema abstrato, existe um "componente ficcional" (CUNHA, 2014, p.59) que se põe materialmente nos filmes, mesmo que seja rarefeito.

Partindo disso, a estética do fluxo vai colocar sob suspeita a ideia de realismo no cinema contemporâneo, já que intensifica "as áreas do real, para atualizar algumas forças, deixando o dito real em seu status aleatório, indeciso, em movimento"7 (BOUQUET, 2002, p.47). Não sem razão, vários teóricos do fluxo utilizam a palavra "ambiguidade" como um adjetivo para a realidade posta em tela ${ }^{8}$.

Existe um mistério na realidade apresentada por filmes como o de Murat, que é potencializado pela dificuldade de se mapear o que

7 "La tâche du cinéaste de flux consiste donc, non à organiser une forme définie pour faire discours, mais à intensifier des zones du réel, à en actualiser certaines puissances, tout en laissant au dit réel son statut aléatoire, indécidé, mouvant."

8 Oliveira Junior evidencia a necessidade de se "respeitar a ambiguidade do real, explorar o acidental e o assignificante, não impor ao mundo um sentido" (2013, p.136). Erly Vieira Junior, indica nos filmes do fluxo a adoção de "um certo tom de ambiguidade visual e textual" (2013, p.490), enquanto Cunha (2014, p.45) aponta como nesse cinema os planos captam "a ambiguidade do real e o devir como mistério". 
realmente está sendo proposto pelas imagens. Por isso a imagem é "surpreendida mais que nunca em uma contradição entre a reivindicação do 'sonho' e o costume e a demanda de realismo" (OLIVEIRA, JUNIOR, 2013, p.137). Não encontraremos em uma análise da narrativa de um filme de fluxo as respostas para esse borramento entre o real e o irreal, mesmo porque estas são muitas vezes insolúveis e quase impossíveis de serem decantadas de uma atmosfera abstrata, que parte da sensorialidade para investigar os "mistérios do mundo" e "as incongruências do real" (CUNHA, 2014, p.20-21). Ou, nas palavras de Olivier Joyard, um cinema que propõe a "radicalidade de uma visão" (2003, p.27) .

\section{TRANSCULTURAÇÃO NARRATIVA E TEMPO MÍTICO}

Ao analisar os processos pelos quais a literatura latino-americana passou ao longo do século XX, Ángel Rama, num texto de 1974, lança algumas observações sobre o que ele denominou a "nova narrativa latino-americana". Essas reflexões seriam ainda mais aprofundadas num ensaio lançado em 1982, La transculturación narrativa en Latinoamérica. No primeiro artigo, Rama observa uma tensão ocorrida na literatura subcontinental da década de 1930, por parte dos movimentos de vanguarda que, construindo um eixo de literatura urbana, através de duas tendências narrativas, a fantástica e a realística-crítica, colidem com uma determinada tradição regionalista de nossa literatura.

A literatura regionalista havia se consolidado como um aporte conservador da representação de nossas sociedades a partir de determinadas particularidades culturais que se cristalizavam tanto no aspecto valorativo quanto nas expressões literárias.

9 "la radicalité d'une vision." 
Dentro da estrutura global da sociedade latino-americana, o regionalismo acentuava as particularidades culturais que haviam sido forjadas em áreas ou sociedades internas, contribuindo para definir seu perfil diferencial. Por isso mostrava propensão pela conservação daqueles elementos do passado que haviam contribuído para o processo de singularização cultural, procurando transmiti-los ao futuro como modelo de preservar a configuração adquirida. (RAMA, 2001, p.211)

O autor reconhecia a importância deste tipo de construção narrativa ao realçar aspectos que caracterizavam as diferenças culturais entre as várias regiões do continente (tema caro aos estudos de Rama), no entanto, a literatura regionalista tendia a engessar as comunidades representadas através de uma enorme distância entre texto, narrador e sociedade. A base desse encontro conflituoso - entre as novas tendências de modernização narrativa e as arcaicas formas de narrar o regional - iria proporcionar uma forma de relato original no universo literário latino-americano, marcada por um processo ao qual o crítico uruguaio chamou de transculturação narrativa, inspirado pelos estudos do antropólogo cubano Fernando Ortiz ${ }^{10}$.

Aprofundando a reflexão original do conceito proposto pelo antropólogo, Rama aponta três operações fundamentais ocorridas no interior das narrativas transculturadas. A primeira se organiza na própria língua, que abandona as estritas características do campo semântico e da ordem sintática regional rumo à construção

10 Em 1940, Fernando Ortiz havia publicado um influente ensaio intitulado Contrapunteo cubano del tabaco y del azúcar, no qual lançava o conceito de transculturação para pensar os processos culturais cubanos, marcados por sincretismos e hibridismos. Desta forma, ele descartava a ideia de aculturação por acreditar que tal conceito não dava conta dos fenômenos mestiços que estiveram presentes na história cultural da ilha. 
de uma atmosfera literária que reconstruía a riqueza destas particularidades das comunidades linguísticas no encontro com as tendências modernizadoras. Assim, o elemento regional deixa de ser "o outro distante" encapsulado pelo olhar de um narrador ocidental para constituir um novo universo literário no qual elementos transculturais se apresentam. Equivalências linguísticas, neologismos e artifícios de linguagem são fundamentais para alcançar uma nova concepção no plano da língua, como muito bem demonstraram as obras de escritores como João Guimarães Rosa, Juan Rulfo ou Gabriel García Márquez, por exemplo.

A segunda instância dos processos transculturais na narrativa se dá no nível da composição literária. O romance regionalista era fruto de uma rígida composição de cunho racionalista e cientificista, que entrava em choque com a liberdade criadora das estratégias das literaturas modernas e vanguardistas. A distância entre estas duas tendências parecia ser algo intransponível, devido às concepções de mundo extremamente opostas a que se filiavam. No entanto, os narradores transculturais conseguiram estabelecer um diálogo bastante profícuo entre modernidade e tradição, como atesta Ángel Rama:

Também aqui a volta ao manancial de cultura tradicional há de fornecer respostas: em vez do fragmentário monólogo interior na linha stream of counsciousness que salpicou imitativamente muita narrativa modernizada, conseguiu-se reconstruir um gênero tão antigo quanto o monólogo discursivo (Grande Sertão: Veredas), cujas fontes estão não só na literatura clássica, como as do narrar espontâneo; ou encontrou-se a solução para o relato episódico e dividido por meio do contar 
dispersivo das "comadres", suas vozes sussurrantes (Pedro Páramo), também composto de fontes orais, embora possa ser rastreado até em textos do Renascimento. (RAMA, 2001, p.221)

O terceiro e último nível abordado por Rama diz respeito aos significados, aquele que encontra as respostas mais engenhosas para os dilemas colocados pelos enfrentamentos entre o gesto tradicional e o espírito modernizador, e que, particularmente neste artigo, nos interessa apresentar como uma pista para revelar os sentidos das imagens no filme de Julia Murat.

Em resposta ao racionalismo cientificista das narrativas tradicionais regionalistas aliadas a um psicologismo sociologizante que construíam as personagens da literatura do século $\mathrm{XIX}$, os narradores transculturadores recorreram a uma cosmovisão que fazia emergir toda uma concepção mítica dos fatos, vinculada aos procedimentos de vanguarda da literatura fantástica do século XX. Desta forma, revelando uma abordagem do mito relacionada ao pensamento pré-ocidental das nossas culturas originárias, os relatos da nova narrativa latino-americana subverteram as formas de verossimilhança e linearidade narrativa aristotélicas, introduzindo elementos do maravilhoso, que também estavam na raiz de nossos textos fundadores, como os testemunhos dos cronistas das Índias. Dessa forma, Rama chega a afirmar que "os transculturadores descobrirão o mito" (RAMA, 2001, p.223).

Curiosamente, nesse ponto ocorre um encontro entre a estética cinematográfica do fluxo e a narrativa proposta pelos transculturadores, que Histórias que só existem quando lembradas saberá explorar com desenvoltura. Ambas as linhas se furtam 
de uma verossimilhança narrativa com intuito de mostrar novas formas de se apresentar a realidade. Nesse processo, a massa fílmica desconexa e de narrativa rarefeita desencadeada pelo fluxo se mostra um espaço fértil para abrigar a subversão da causalidade proposta pelos transculturadores.

Abandonando o tom folclorista que muitas vezes engessava a abordagem das culturas regionais, remetendo à improdutiva perspectiva da "cor local", os narradores transculturadores vão ressignificar as falas populares, as vozes originárias e nossas crenças não ocidentais, contagiando nossa literatura de um poderoso pensamento mítico, que organizará, não sem tensão, o encontro daquilo que nos é próprio com aquilo que nos é alheio. Neste procedimento revela-se um universo repleto de ambiguidade e de uma profusa inventividade ao acolher as culturas rurais e regionais sob um novo e criativo prisma.

Portanto, a resposta à desaculturação que nesse nível dos significados o irracionalismo vanguardista promove, parece em primeiro lugar simplesmente confirmar a proposta modernizadora, rendendose a ela. Porém, na realidade, supera-a com uma riqueza imprevisível a que poucos escritores da "modernidade" foram capazes de chegar: ao manejo dos "mitos literários" oporá o "pensar mítico". (RAMA, 2001, p.224)

O romance de Rulfo, bem como o filme de Murat, narra a chegada de uma personagem a um universo rural ao qual o forasteiro não pertence. O não pertencimento é um elemento importante nas narrativas, uma vez que muito do estranhamento provocado pela atmosfera que se constrói se dá não exatamente por um 
choque entre as duas perspectivas, mas pelas dessemelhanças que provocam o encantamento das imagens reveladas. Logo no início do romance, esse traço emerge como um indicativo importante, quando Juan Preciado, diante dos aspectos sensíveis evocados pelo lugar, reflete:

"Volvió a darme las buenas noches. Y aunque no había niños jugando ni palomas, ni tejados azules, sentí que el pueblo vivía. Y que si yo escuchaba solamente el silencio, era porque aún no estaba acostumbrado al silencio; tal vez porque mi cabeza venía llena de ruidos y de voces ${ }^{11 "}$ (RULFO, 2000, p.69).

Percebemos que a distância evocada pelos dois mundos também se dá pela instância sonora que emoldura a narrativa, destacando a importância das várias camadas de som que produzem sentido nesta perspectiva do estranhamento, desde o silêncio, até os ruídos e vozes. Ao longo de todo o romance, o som é imperativo para o reconhecimento do espaço insólito que se constrói.

Também em Histórias que só existem quando lembradas, o som, de certa forma, organiza a experiência daquele universo, construído por vozes dissonantes sussurradas na escuridão, em muito associadas aos ruídos da natureza, o vento, o barulho dos pássaros e o silêncio perturbador que se instaura no ambiente, gesto também presente em Rulfo: "Entonces ella se dio vuelta. Apagó la llama de la vela. Cerró la puerta y abrió sus sollozos,

11 "Tornou a me dar boa-noite. E embora não houvesse crianças brincando, nem pombas, nem telhados azuis, senti que o povoado vivia. E que se eu escutava somente o silêncio era porque ainda não estava acostumado ao silêncio; talvez porque minha cabeça viesse cheia de ruídos e de vozes" (p.20). Os trechos traduzidos de Pedro Páramo neste artigo são de autoria de Eric Nepomuceno na segunda edição do romance publicada em 2011 pela BestBolso, Rio de Janeiro. 
que se siguieron oyendo confundidos con la lluvia ${ }^{12 " \prime}$ (2001, p.77). Aqui percebemos uma dimensão muito importante disso que se refere à abordagem mítica indicada por Ángel Rama. Ao misturar os ruídos dos soluços ao som da chuva, o narrador desconstrói a separação entre homem e natureza, tão cara à cultura ocidental, e que é absolutamente contrária à perspectiva existencial dos povos originários ${ }^{13}$. Essa abordagem atravessa toda a obra de Rulfo, construindo em Comala um território marcado por uma cosmovisão destoante da concepção de uma perspectiva ocidental. Este ponto, como veremos a seguir, será central no filme de Murat.

\section{HISTÓRIAS QUE SÓ EXISTEM QUANDO LEMBRADAS}

Todos os dias, antes do raiar do sol, a idosa Madalena acorda para produzir o pão. A tarefa de misturar os ingredientes segue uma receita impregnada na memória, mas que para nós, espectadores, nunca será revelada. O pão pronto é levado em um cesto, que Madalena carrega ao atravessar a linha de trem abandonada até chegar à bodega. Por todo o trajeto surgem casas fechadas e degradadas pelo tempo, em ruas sempre desertas. Na bodega essa atmosfera do abandono se reproduz: nada vemos nas prateleiras além do café e do pão e só isso já é suficiente para desencadear diariamente as teimosias da personagem com Antônio, o dono da venda. Os dois sentam-se para tomar café enquanto o sino da igreja ressoa: é hora da missa. $\mathrm{Na}$ igreja, também abatida pelo tempo, a personagem é acompanhada

12 "Então ela se virou. Apagou a chama da vela. Fechou a porta e abriu seus soluços, que continuaram sendo ouvidos confundidos com a chuva" (p.27).

13 Podemos pensar ainda numa espécie de citação a La Llorona, mito importante da cultura mexicana, originária da tradição azteca. Dentre as várias versões da lenda, em parte correspondente ao mito trágico de Medeia, está a história de uma mulher que, arrependida de ter assassinado seus filhos por causa do amor por um homem, costumava aparecer nas noites de chuva soluçando em busca de suas crianças. 
por uma dúzia de idosos, que equilibram o enquadramento da imagem cinematográfica, dividida ao meio pelo caminho para o altar. Na cena seguinte, Madalena está sozinha mais uma vez, rega algumas plantas na frente do cemitério, que estranhamente tem o portão fechado a cadeado. Já é hora do almoço, compartilhado por um grupo de idosos em volta da mesa. Após isso a personagem volta para casa, passando novamente pela linha do trem enquanto alguns idosos jogam bocha na plataforma abandonada. Durante a noite Madalena escreve uma carta para seu marido. As próximas cenas são iluminadas parcialmente por uma lamparina, que mostra o caminhar de Madalena pela escuridão e o fazer do pão, elucidando o surgimento de uma rotina idêntica à do dia anterior.

A repetição dessa rotina, que se manterá durante todo o filme, desencadeia a apreensão de um tempo circular, no qual a linearidade é substituída pelo tempo de um dia, que em sua essência é sempre o mesmo. Assim como o romance de Rulfo, a narrativa se oferece por meio de fragmentos, sem começo nem fim, como "fragmentos de imagem", frágeis em sua habilidade narrativa tradicional, capturadas de maneira fantasmática, evanescente, prontas a se dissiparem no momento seguinte. O tempo do filme, acompanhando o tempo do romance, não é linear. Não é possível afirmar o quanto o tempo avança na narrativa, uma vez que não se pode medí-lo linearmente, mas observá-lo em sua forma cíclica e ininterrupta, como o disco que gira sobre o prato da vitrola, imagem-metáfora da circularidade do tempo presente no filme, e que também emerge através do narrador de Pedro Páramo:

En el hidrante las gotas caen una tras otra. Una oye, salida de la piedra, el agua clara caer sobre el 
cántaro. Uno oye. Oye rumores; pies que raspan el suelo, que caminan, que van y vienen. Las gotas siguen cayendo sin cesar. El cántaro se desborda haciendo rodar el agua sobre un suelo mojado. (RULFO, 2001, p.85) $)^{14}$

Estamos diante de um tempo esvaziado de significados, que não é capaz de promover o encadeamento de ações em uma lógica de causa e efeito. O filme nos propõe "sussurros de imagem", fragmentadas, incompreensíveis no seu desprezo à integralidade, tais como o "contar dispersivo das comadres" em Pedro Páramo; imagens que são capturadas de forma aparentemente espontânea e aleatória, descomprometidas de qualquer função organizadora de inteligibilidade para a narrativa. Aliás, isso nos remete ao nível da composição narrativa apresentado por Ángel Rama sobre o processo de transculturação: a estabilidade do relato no filme - mas também no romance apresentado através de 68 fragmentos - é colocada em xeque por uma abordagem lacunar. A concepção racionalizadora da narrativa clássica, marcada pela inteligibilidade, pelo princípio cognitivista, é estraçalhada por uma forma de perceber o filme através de outras possibilidades, não mais pelo entendimento do que se passa, não mais engendrado pelo pressuposto da causalidade aristotélica, mas por meio desse "contar dispersivo e hesitante", onde "o plano do verossímil possa funcionar contiguamente ao plano do fantástico" (RAMA, 2001, p.221).

Trata-se de um tempo-espaço lacunar, fissurado, como as paredes das casas e os rostos dos idosos, por elipses, tão utilizadas 
pelos cineastas do fluxo e que impedem a visualização de qualquer fato que transgrida o trânsito de Madalena, que se dissipa assim que a personagem muda para outro espaço. Como a Comala de Pedro Páramo, Jotuomba é uma vila campestre, desterritorializada e com um reduzido número de habitantes, ambientação que também é recorrente em outros filmes do cinema de fluxo ${ }^{15}$. Talvez por isso, Jotuomba nunca seja enquadrada como um todo, mas apenas por fragmentos desse espaço.

Dessa forma, em seus primeiros 20 minutos Histórias que só existem quando lembradas é como uma receita repetida diariamente. Essa estrutura, que soa ao perpétuo e intransponível, promove uma sensação de estranhamento perante o real, já que Murat tem menos a intenção de captar a realidade e mais de evidenciar o fugidio, inserindo uma realidade opaca, que esconde atrás de um véu naturalista suas ambiguidades e incertezas. Nesse meio, o insólito se instaura como elemento perturbador de uma narrativa tradicional, trazendo o estranhamento, tanto no aspecto do relato quanto na perspectiva da linguagem: a caixa repleta de cartas escritas e jamais postadas, o deslocamento das personagens no escuro, a incômoda simetria na concepção dos quadros, o cemitério fechado pela falta de registro de mortos, a palidez de uma paleta de cores como se a própria imagem fílmica estivesse também desbotando.

Esse princípio do desaparecimento potencializa o aspecto temporal que impacta de forma determinante naquilo que Rama introduz como o terceiro nível narrativo a ser afetado pelo processo 15 Emiliano Fischer Cunha (2014) aponta entre os elementos que compõem o cinema de fluxo a sensação de escapismo, em filmes que ou passam em lugares afastados ou seus protagonistas estão em busca de afastamento dos grandes centros urbanos. 
de transculturação: o nível dos significados. Essa temporalidade do filme é construída também por uma câmera quase sempre fixa, contemplativa, que observa os personagens com certo encantamento, sem nenhuma intenção de apresentá-los por meio de fatos e informações, mas, sobretudo, por fragmentos de corpos que se deslocam lenta e furtivamente pelas sombras, mal iluminados pela tênue luz dos lampiões. Assim, a câmera não interroga o que capta: sua intenção, ao respeitar a lógica desse espaço, é instaurar um tempo particular do filme, que parece escapar completamente do determinismo de um tempo histórico. A interação entre a estética do fluxo e uma tradição literária latino-americana, cria um espaço ambíguo, mas que, consentido pelos personagens e pela câmera, só é ostensivo para o espectador. Porém, o filme não nos deixa sozinhos nessa angústia e põe em cena a jovem fotógrafa Rita, que sem sua presença, ousamos dizer, faria a narrativa se repetir em perpétua rotação. Pouco sabemos sobre a personagem, apenas que chegou seguindo uma trilha e que, como muitos personagens do cinema de fluxo, está presa "na fronteira entre o estar e o seguir, entre o pertencer e o não-pertencer" (CUNHA, 2014, p.47).

Sua função inicial é de datar a contemporaneidade do tempo narrativo, por meio da forma que se veste e dos objetos que carrega (câmera digital e MP3). Mas sua real potência está em perturbar a lógica temporal e de nos fazer transitar juntos com ela por espaços antes relegados. Isso ocorre já no primeiro encontro com Madalena, quando a idosa aceita abrigá-la em sua casa. Assim, se nos dias anteriores a casa de Madalena era mostrada somente durante a noite, agora a idosa é obrigada a abrir as janelas, para que a luz natural entre e mostre um caminho novo para a câmera 
seguir. Um espaço que estava apagado para a própria dona da casa, que descansava na escuridão, mas que com a chegada de Rita é revivido à força.

Talvez por sentir essa sensação de abandono Rita se adiante e escolha seu próprio quarto, enquanto Madalena reencontra em cima de uma cadeira uma camisa de seu marido. Quando o marido de Madalena morreu? Há quanto tempo essa camisa repousa nesta cadeira? Estas são perguntas que o silêncio narrativo e o tempo mítico tornam o filme incapaz de responder.

Durante a noite, a presença de Rita atrapalha a rotina de Madalena e, por isso, na manhã seguinte, a protagonista chega atrasada na mercearia, quando as portas já estão abertas e Antônio moendo o café. Agora a conversa despretensiosa entre os dois tem um novo assunto: "O que você acha dos jovens?", indagação que funciona como uma primeira fagulha de uma série de conversas que o casal de idosos terá sobre suas juventudes. Essa é uma função essencial de Rita dentro do filme: desencadear nos moradores locais memórias que pareciam esquecidas e que remetiam a um tempo cronológico.

A rotina tenta se perpetuar e nos leva novamente para a igreja. Porém, ao invés de se prender aos moradores, o enquadramento se liberta e apresenta um prado delimitado pela moldura de uma janela circular da igreja. Essa resistência também é vista no cemitério, no qual o quadro é construído de dentro das grades, ou seja, no espaço proibido aos moradores. Isso ocorre mesmo quando a câmera não parece preparada. Durante a noite Rita sai de casa e, "surpresa" com a atitude, a câmera quebra sua premissa de fixidez e persegue 
com instabilidade o caminhar da personagem pela escuridão. Nessa sequência algo sai do "combinado", e a partir desse momento a câmera não se conformará mais à estrutura imposta e se colocará também ao lado da jovem, entendendo que seu tráfego pelo vilarejo possibilita o desbravar de novas situações.

Justamente em uma dessas saídas noturnas, a câmera capta a imagem mais disruptiva do deslocamento no filme, quando a menina, usando fones de ouvido, e assumindo a subjetividade auditiva do plano, performatiza uma dança que curtocircuita a estrutura sonora da película. Seus gestos, que encenam essa ruptura, entram em colisão com o movimento lento impresso pelas outras personagens e dimensionam a distância entre os dois movimentos, criando um estranho desconforto no espectador.

Com isso, a temporalidade circular passa a ser preenchida pelo olhar de Rita, que se desloca pelos espaços rotineiros fracionando as imagens a partir de seu ponto de vista, particularizando objetos e atentando aos detalhes que o plano geral omitia. Rita é uma estrangeira, uma invasora que caminha pelo espaço do outro questionando sua lógica. Interrogando como o espectador gostaria de fazer se estivesse no vilarejo e, não sem razão, Murat faz com que em diversos momentos compartilhemos de seu ponto de vista minucioso. Além disso, Rita está munida de três câmeras (uma pinhole, uma analógica e uma digital), captando a evanescência desse território para fixá-la em papel fotossensível, transformá-la em registro. $\mathrm{O}$ ato de fotografar é aqui, mais do que nunca, uma forma de assegurar a existência, não só do que é registrado, mas também da própria fotógrafa. Por isso, a personagem improvisa um estúdio no quarto, pois é necessário transformar as imagens captadas em 
memórias, em materialidades fixadas no papel. Porém são imagens que borram a fronteira entre vivos e mortos, que convivem na Comala de Rulfo e na Jotuomba de Murat, através de registros que parecem fadados ao desaparecimento, ou sujeitos às lacunas da memória. 0 que se vê como resultado são imagens fragmentadas e incompletas, retratos fugidios que não chegam a integralizar com nitidez o rosto dos fotografados, tornando-se ecos de si mesmo.

Este pueblo está lleno de ecos. Tal parece que estuvieran encerrados en el hueco de las paredes o debajo de las piedras. Cuando caminas, sientes que te van pisando los pasos. Oyes crujidos. Risas. Unas risas ya muy viejas, como cansadas de reír. $Y$ voces ya desgastadas por el uso. Todo eso oyes. Pienso que llegará el día en que estos sonidos se apaguen. (RULFO, 2001, p.103) $)^{16}$

A relação ambígua com o real, que o filme potencializa ao se associar a estética do fluxo, se emparelha com a noção de fotografia insólita proposta por Julio Cortázar (1978), para quem a fotografia se mostra como uma forma de captar uma segunda realidade, não visível em primeira instância. Para ele, uma fotografia insólita pode ser criada tanto pelo excepcional quanto pelo inesperado. Intenção e coincidência são as duas formas de se captar o sobrenatural, mas no último caso, em que o extraordinário é descoberto pelo fotógrafo apenas após o processo de revelação da foto ${ }^{17}$, é ainda mais extraordinário: "se uma irrupção não pretendida talvez seja mais bela e mais intensa, também é bom que o fotógrafo para-raios 16 "Esta cidade está cheia de ecos. Parece até que estão trancados no oco das paredes ou debaixo das pedras. Quando você caminha, sente que vão pisando seus passos. Ouve rangidos. Risos. Umas risadas já muito velhas, como cansadas de rir. E vozes já desgastadas pelo uso. Você ouve tudo isso. Acho que vai chegar o dia em que esses sons se apagarão" (p.53).

17 É bom pontuar que o texto de Cortázar é de 1978, portanto, anterior à câmera digital. 
vá à rua com a esperança de encontrá-la; toda provocação de forças não legisláveis conquista um dia a sua recompensa, embora esta possa se dar como surpresa e mesmo como pavor" (CORTÁZAR, 2010, p.416). Assim, criar uma imagem insólita é algo extremamente complicado. A esse respeito o próprio Cortázar confessa que suas fotografias "sempre foram uma amável réplica do que eu pretendia no instante de tirá-las" (p.418). E a partir disso teoriza o próprio sobrenatural: "como se vê, o meu sentimento do insólito na fotografia não é lá muito verificável. Mas não é precisamente isso a marca do insólito?" (p.420).

Como alguns personagens de Cortázar ${ }^{18}$, Rita capta em suas fotografias mais do que esses cenários são capazes de apresentar em sua primeira camada. Se as fotos ganharam esses contornos por algum procedimento na exposição ou revelação, ou se captam uma segunda realidade, insinuando a captação da alma, o mais importante é que essas fotografias nos fornecem mais uma pista de como esse espaço revela ambiguidades. Juntando-se ao segredo do cemitério fechado, mantido pelas trocas de olhares entre os personagens e as frases jogadas ao vento como "aqui a gente esquece de morrer" ou "então morre, você pode vir quando quiser".

O insólito é, como aponta Rosalba Campra (2016) ao falar do fantástico contemporâneo, construído através de transgressões do nível sintático, que aqui se constituem a partir de traços do cinema fluxo - duração dos planos, apreensão do cotidiano, minimização da narrativa e uma montagem lacunada por elipses. Efeitos que a 18 Cortázar nos oferece exemplos em dois de seus contos. Em As Babas do Diabo, narrado por um defunto, a fotografia é colocada como elemento central para a resolução de um mistério, que só pode ser descoberto pela revelação e ampliação de uma imagem. Já em Apocalipse de Solentiname (1981), a fotografia se une ao insólito como forma de antevisão ao futuro tenebroso da Nicarágua. 
atmosfera do filme produz e que não deixam de criar hesitações (TODOROV, 2010) como é comum ao fantástico:

O escorrer das imagens do fluxo nos oferece um lugar dialético entre a descoberta e o desconforto. Diante de um processo narrativo interdito e imerso em um enleio de puro descobrimento daquelas imagens, o espectador é conduzido - ou melhor, convidado - a trilhar um caminho no qual ele não está familiarizado. Nessa trilha florescem duas sensações incômodas: a de estranheza e desorientação. (ORSINI, 2017, p.88)

A "lógica da sensação (e não da encenação)" (OLIVEIRA JUNIOR, 2013, p.151), muitas vezes impossibilita saber qual o teor das imagens: o que é real, sonho, sobrenatural ou cotidiano é nublado por uma sensação perpétua de estranhamento.

Histórias que só existem quando lembradas não tem intenção de quebrar com essa atmosfera. Mesmo que as memórias desencadeadas em Madalena a levem ao confronto com seu passado - o filho que morreu após tirar um retrato, o casamento com o marido -, criando um ruído entre o passado e o presente e por isso resolvendo morrer, a temporalidade circular ainda é respeitada. Madalena morre, mas não sem antes tirar um retrato que comprove a sua existência, mesmo que se trate de uma existência fantasmagórica.

Entretanto, a afetação entre Madalena e Rita não é de mão única. Se inicialmente Rita parece ser uma personagem de um mundo real e urbano transportada "magicamente" para esse vilarejo, com o passar do tempo ela também é contaminada pela temporalidade que a cidade propõe. Uma cena representa bem esse processo. 
Durante um inesperado baile entre os idosos, Rita se senta ao lado da vitrola que anima a festa, o disco termina de forma inesperada e a personagem vira o disco para tocá-lo do outro lado. Porém, no meio do movimento é surpreendida por Antônio que a convence a tocar o mesmo lado de novo. Como a vitrola que toca sempre as mesmas músicas, a narrativa do filme tenta ao máximo perpetuar o ciclo inicial, rotina a qual Rita começa a ser incorporada.

Assim, ao conviver com Madalena, Rita se envolve em sua rotina, herda a chave da casa e aprende a fazer o pão. Se desde do início existe na personagem uma sensação de incompatibilidade e há necessidade em partir, com a morte de Madalena, a personagem se torna a única capaz de fazer o pão e com isso manter Jotuomba em seu ciclo perpétuo.

\section{CONCLUSÃO}

Neste artigo partimos de Histórias que só existem quando lembradas com o intuito de investigar como o insólito se constrói em um filme que não apresenta uma narrativa clara e objetiva, já que o gesto de Julia Murat é o de desbotar as fronteiras entre memória e esquecimento por meio de uma temporalidade circular, pontuada por acontecimentos mínimos e cotidianos, que se ligam à lógica das sensações.

Por isso, nossa análise pautou-se pela evidenciação de um espaço-tempo insólito, capaz de combinar a teoria sobre a estética do fluxo com pistas oriundas da literatura (Pedro Páramo e a análise de Ángel Rama sobre a transculturação na narrativa latinoamericana). Esse procedimento conjugou pontos de vista literário e cinematográfico que curiosamente se encontram na pulverização 
de uma narrativa aristotélica e na intenção de apresentarem um novo olhar sobre a realidade.

Como o espaço no qual habitam as personagens Madalena e Rita, essas teorias estabelecem fronteiras movediças que, na massa disforme e contínua que o filme propõe, dão projeção ao sobrenatural ao mesmo tempo em que limitam seu poder de definição. Nesse meio, a ideia de real "opaco", "ambíguo" e "misterioso," pontuada pelos teóricos do fluxo, cria uma atmosfera de estranhamento perante as imagens e os sons, que possibilita a absorção dos elementos insólitos, que não necessitam de um arco narrativo claro para sua existência. Assim, o insólito no referido filme se cria a partir de "imagens sussurrantes", cuja evanescência é possibilitada pela união de um tempo mítico (oriundo da influência de Pedro Páramo e dos transculturados no filme), com os elementos estéticos que o cinema de fluxo introduz a partir da dilatação do plano, dos silêncios narrativos e das fissuras deixadas pelas elipses.

\section{REFERÊNCIAS}

BOUQUET, Stéphanie (2002). Plan contre flux. Paris: Cahiers du Cinema n.566.

CAMPRA, Rosalba (2016). Territórios da Ficção Fantástica. Rio de Janeiro: Dialogarts Publicações.

CORTÁZAR, Julio (2010). "Janelas para o Insólito". In: Papéis Inesperados. Rio de Janeiro: Editora Civilização Brasileira.

CUNHA, Emiliano Fischer (2014). Cinema de Fluxo no Brasil: Filmes que pensam o Sensivel. Dissertação apresentada como requisito para a obtenção do título de Mestre pelo Programa de Pós-Graduação em Comunicação Social da Pontifícia Universidade Católica do Rio Grande do Sul - PUCRS.

JOYARD, Olivier (2003). C'est quoi ce plan? (la suite). Paris: Cahiers du Cinema n.580.

LALANNE, Jean-Marc (2002). C'est quoi ce plan?. Paris: Cahiers du Cinema n.569. 
OLIVEIRA JR. Luiz Carlos (2013). A mise-en-scène no cinema. Campinas: Editora Papirus.

ORSINI, Gian (2017). Do plano-sequência ao fluxo: aspectos temporais, narrativos e estilísticos no plano de longa duração no cinema contemporâneo. Dissertação apresentada ao Programa de Pós-Graduação em Comunicação da Universidade Federal Fluminense, como requisito para obtenção do título de Mestre.

RAMA, Ángel (2001). "Os Processos de Tansculturação na narrativa latinoamericana". In: Literatura e cultura na América latina. São Paulo: Edusp.

RULFO, Juan (2000). Pedro Páramo. Madrid: Cátedra.

RULFO, Juan (2011). Pedro Páramo. Rio de Janeiro: BestBolso.

TODOROV, Tzvetan (2010). Introdução à Literatura Fantástica. São Paulo: Editora Perspectiva. 